\title{
Workshop Kreasi Sorbet Berbahan Buah Dan Sayur Untuk Siswa Sekolah Lentera Harapan (SLH) Curug Tangerang
}

\author{
Yustisia Kristiana ${ }^{1}$, Reagan Brian ${ }^{2}$ \\ ${ }^{12}$ Universitas Pelita Harapan
}

yustisia.kristiana@uph.edu, reagan.brian@uph.edu

\begin{abstract}
Abstrak
Anak-anak sering bermasalah dalam mengonsumsi makanan yang memenuhi kebutuhan gizi karena anak-anak cenderung memilih makanan tertentu yang disukai saja. Hasil riset Pusat Penelitian dan Pengembangan Upaya Kesehatan Masyarakat pada tahun 2014 menyebutkan bahwa sebesar 98,4\% remaja kurang konsumsi sayur dan buah. Usia remaja pada umumnya dikaitkan dengan usia sekolah yaitu siswa SMP. Golongan usia SMP pada umumnya memiliki kebiasaan untuk memilih dan membeli sendiri makanan yang dikonsumsi. Pemilihan makanan pada usia ini bukan didasarkan pada manfaat kesehatan, namun lebih kepada warna yang menarik dan rasa yang sesuai dengan lidah. Hal ini dikarenakan kurangnya kesadaran dan pengetahuan siswa SMP tentang manfaat dari buah dan sayur dan kreasi makanan sehat berbahan buah dan sayur. Berdasarkan penjelasan tersebut maka perlu disiasati agar anak-anak tetap mendapatkan asupan buah dan sayur, salah satunya adalah melalui makanan penutup yaitu sorbet. Solusi yang ditawarkan adalah dengan memberikan penyuluhan tentang manfaat buah dan sayur dan workshop tentang kreasi sorbet berbahan buah dan sayur. Kegiatan ini diikuti oleh siswa SMP dari Sekolah Lentera Harapan (SLH) Curug. Metode yang dilakukan yaitu melakukan persiapan, antara lain berkoordinasi dengan pihak sekolah, penyusunan materi dan uji coba produk. Tahap kedua adalah mengadakan penyuluhan maupun workshop untuk meningkatkan pengetahuan tentang manfaat buah dan sayur serta kreasi sorbet berbahan buah dan sayur. Tahap terakhir merupakan tahap evaluasi. Kegiatan ini berjalan dengan lancar diikuti oleh 30 siswa dan para peserta mendapatkan edukasi tentang sorbet dan cara membuatnya.
\end{abstract}

Kata Kunci: remaja, makanan penutup, sorbet

\section{PENDAHULUAN}

Pada usia anak-anak, makanan ringan merupakan salah satu bentuk makanan yang dikonsumsi dalam jumlah banyak dan memberikan kontribusi yang cukup tinggi terhadap kecukupan energi dan zat gizi. Anak-anak sering bermasalah dalam mengonsumsi makanan yang memenuhi kebutuhan gizi karena anak-anak cenderung memilih makanan tertentu yang disukai saja. Karakteristik rasa, warna, bentuk yang lucu dan menarik, seringkali menjadi faktor penentu anak dalam memilih makanan (Proverawati, Prawirohartono dan Kunjjoro, 2008).

Hasil riset Pusat Penelitian dan Pengembangan Upaya Kesehatan Masyarakat pada tahun 2014 menyebutkan bahwa sebesar 98,4\% remaja kurang konsumsi sayur dan buah. Ketidaksukaan seseorang pada buah atau sayuran bisa disebabkan oleh dua faktor yaitu food neophobia dan picky/fussy eating. Food neophobia secara umum adalah keengganan untuk makan atau menghindari makanan baru. Sementara picky/fussy eating bisa dicontohkan dengan anak yang mengonsumsi banyak jenis makanan dan melakukan

$$
\text { Ekonomi,Sosial,dan Budaya } 956
$$


pemilihan dengan menyaring makanan yang serupa alias dipilih satu saja (Dovey et al., 2008).

Anak pada usia sekolah dengan aktivitas yang tinggi akan memengaruhi pemilihan makanan. Golongan usia SMP pada umumnya memiliki kebiasaan untuk memilih dan membeli sendiri makanan yang dikonsumsi. Pemilihan makanan pada usia ini bukan didasarkan pada manfaat kesehatan, namun lebih kepada warna yang menarik dan rasa yang sesuai dengan lidah.

Berdasarkan penjelasan tersebut maka perlu disiasati agar anak-anak tetap mendapatkan asupan buah dan sayur, salah satunya adalah melalui makanan penutup yaitu sorbet. Sorbet merupakan hidangan penutup yang terbuat dari jus buah dengan air dan gula atau pemanis lainnya yang dibekukan seperti es krim, namun tidak mengandung susu. Kandungan vitamin dalam sorbet tergolong banyak dan baik untuk tubuh. Dalam setiap sajian sorbet (satu cangkir), terdapat kandungan nutrisi yang berbeda-beda, tergantung pemilihan bahan yang digunakan untuk membuat sorbet. Sorbet sendiri dapat diolah dari berbagai macam buah segar atau cokelat. Rata-rata setiap satu cangkir kurang lebih 200 gram per penyajian mengandung 175 kalori. Sekitar 160 kalori berasal dari karbohidrat, 10 kalori protein dan 5 kalori lemak. Sorbet adalah salah satu kudapan yang rendah kalori jika dibandingkan dengan satu cangkir es krim yaitu 267 kalori atau satu cangkir frozen yogurt yaitu sebesar 214. Selain kandungan kalori yang lebih rendah, jumlah gula yang terdapat pada kudapan sehat ini juga relatif aman. Satu sajiannya atau sekitar 200 gram mengandung rata-rata 34 gram gula. Sementara itu, es krim dalam takaran yang sama menawarkan 44 gram gula, dan yoghurt dalam takaran yang sama mengandung 38 gram gula. Sorbet yang terbuat dari bahan-bahan asli tanpa campuran krim atau susu membuat rasa manis alami (Anindyaputri, 2019).

Sorbet yang terbuat dari buah-buahan memiliki kandungan pemanis alami yang khas. Hal ini cocok dengan remaja yang menurut hasil penelitian Sartika (2010) menyatakan bahwa berdasarkan preferensi, tercatat $85 \%$ remaja SMP menyukai makanan manis. Sorbet biasanya memiliki tekstur yang lebih kasar dari es krim. Perkembangan di bidang pangan menyebabkan sorbet tidak hanya terbuat dari sari buah-buahan, namun juga yang bahan lainnya, diantaranya adalah sayur.
Sekolah Lentera Harapan (SLH) Curug yang beralamat Jl. Elang 1B, Suka Bakti, Kecamatan Curug, Tangerang, Banten merupakan sekolah di bawah Yayasan Pendidikan Pelita Harapan yang mendidik sekitar 280 siswa SMP. Di dalam sekolah ini terdapat kantin sekolah. Namun seperti remaja pada umumnya, siswa SLH Curug juga kurang suka untuk mengonsumsi buah dan sayur, sehingga banyak yang memilih membeli makanan di luar kantin sekolah yang kemungkinan besar tidak berbahan buah dan sayur.

Permasalahan yang dihadapi mitra adalah (1) kurangnya kesadaran dan pengetahuan siswa SMP tentang manfaat dari buah dan sayur serta dan (2) kurangnya pengetahuan tentang kreasi makanan sehat berbahan buah dan sayur. Solusi yang ditawarkan untuk mengatasi permasalahan yang dihadapi oleh mitra adalah dengan penyelenggaraan kegiatan yaitu (1) memberikan penyuluhan tentang manfaat buah dan sayur bagi anak-anak. Penyuluhan ini bertujuan untuk meningkatkan pengetahuan siswa tentang manfaat buah dan sayur, dan (2) memberikan workshop tentang kreasi sorbet berbahan buah dan sayur. Workshop ini bertujuan untuk menumbuhkan kreasi siswa tentang sorbet dengan bahan buah dan sayur sehingga nantinya meningkatkan konsumsi buah dan sayur pada para siswa.

\section{METODE}

Bentuk kegiatan yang dilaksanakan adalah workshop kepada para siswa SLH. Metode workshop digunakan untuk proses alih keterampilan kepada siswa. Tidak lanjut kegiatan workshop tersebut yaitu siswa dapat membuat hidangan penutup yang sehat untuk dikonsumsi. Workshop sebagai salah satu program pembelajaran dapat dilakukan melalui tahapan perencanaan, pelaksanaan, dan evaluasi (Basleman dan Mappa, 2011).

Tahap awal pelaksanaan ini adalah tahap persiapan. Pada tahap persiapan, tim melakukan pertemuan dengan pihak sekolah untuk berkoordinasi dalam mensosialiasikan program kegiatan serta penentuan peserta yang akan mengikuti kegiatan. Dalam tahapan ini, tim mempersiapkan materi yang akan diberikan dan melakukan uji coba untuk produk sorbet yang akan

$$
\text { Ekonomi,Sosial,dan Budaya }
$$


diajarkan. Sorbet adalah salah satu produk frozen dessert, yang dibuat dari sari buah beku yang ditambah gula dan penstabil serta tidak mengandung lemak (Scehule dan Bennion, 2015). Terdapat beberapa bahan penstabil yang sering ditambahkan untuk menjadi bahan penstabil seperti CMC (Carboxylmetyl Cellulose), keragenan, agar-agar, gum arab dan sebagainya (Nur, 2012). Cara pembuatan sorbet adalah sebagai berikut:

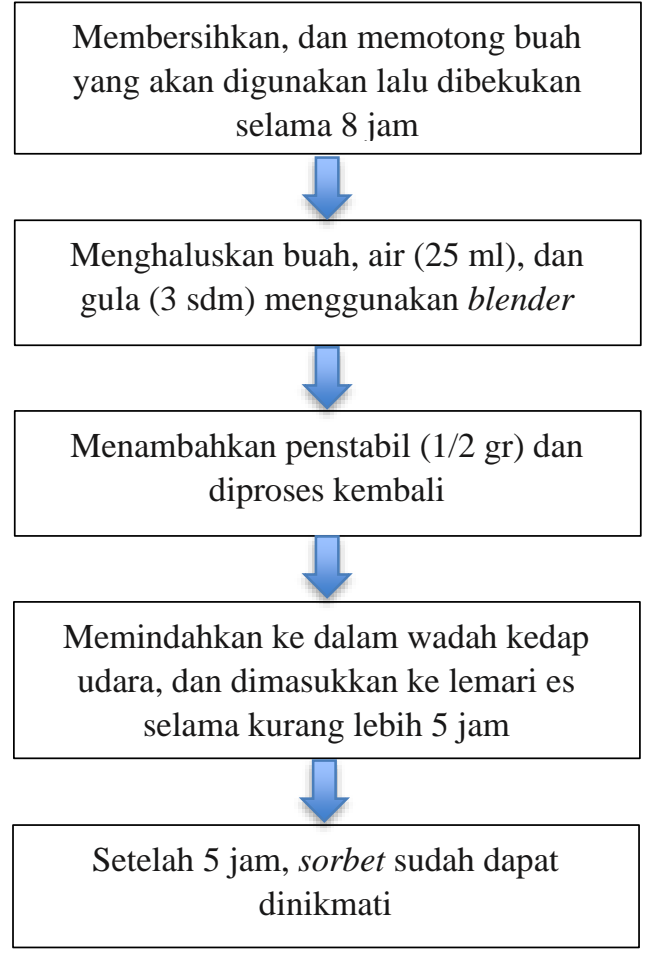

Gambar 1. Cara Pembuatan Sorbet

Resep yang telah diujikan dibuat dengan desain yang menarik agar siswa semangat dalam mengikuti workshop.

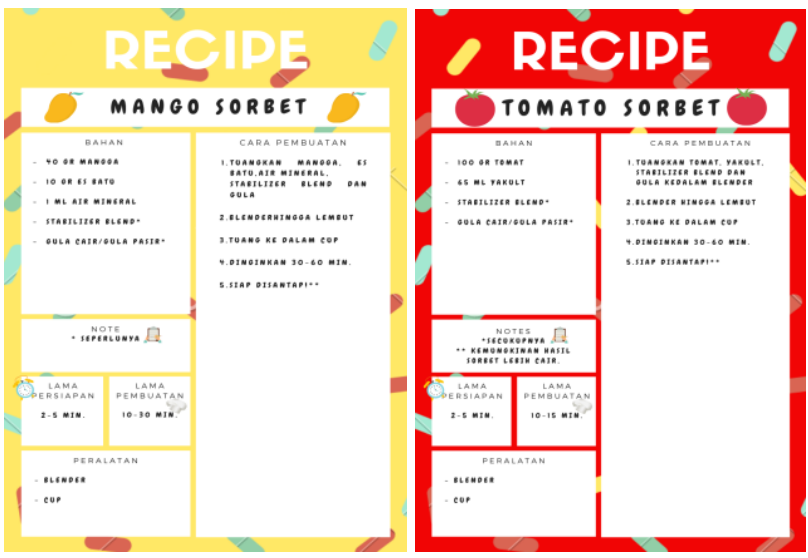

Gambar 2. Desain Resep Sorbet

Tahap kedua adalah mengadakan penyuluhan maupun workshop untuk meningkatkan pengetahuan tentang manfaat buah dan sayur serta kreasi sorbet berbahan buah dan sayur. Pada saat workshop, peserta dapat langsung mempraktikkan cara pembuatan sorbet.

Tahap terakhir merupakan tahap evaluasi. Pada akhir kegiatan, tim memberikan angket evaluasi kegiatan untuk mengetahui manfaat penyelenggaraan kegiatan bagi siswa.

\section{HASIL DAN PEMBAHASAN}

\section{Pelaksanaan Kegiatan PkM}

Kegiatan Pengabdian kepada Masyarakat (PKM) di Sekolah Lentera Harapan (SLH) Curug Tangerang, dan tim melakukan persiapan. Kegiatan diawali dengan registrasi dan dilanjutkan dengan pembukaan.

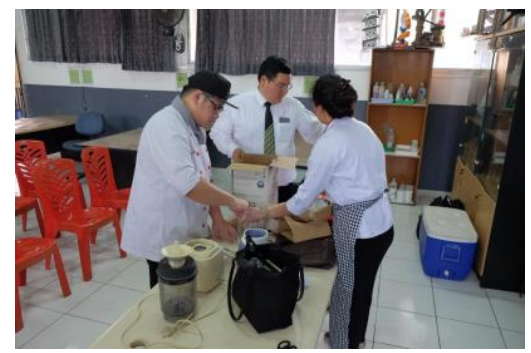

Gambar 3. Persiapan Kegiatan PkM 
Workshop dipimpin oleh tim yang dimulai dengan pembagian kelompok dan bahan, penjelasan tentang manfaat buah dan sayur serta sorbet, dan kemudian pembuatan sorbet oleh para siswa. Sorbet yang diajarkan kepada siswa adalah sorbet mangga dan tomat. Kegiatan ini diikuti oleh 30 orang siswa.

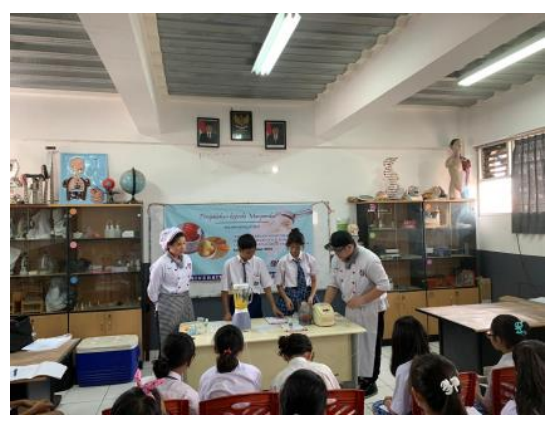

Gambar 4. Pelaksanaan Kegiatan PkM

Kegiatan PkM diakhiri dengan doa penutup, foto bersama, dan penyerahan souvenir kepada Bapak Josep Nasrani Marbun, M.Pd. sebagai Kepala Sekolah SMP Sekolah Lentera Harapan (SLH) Curug dan guru pembimbing kegiatan tata boga yaitu Ibu Rosita Lolok Tage, S.Pd. Berikut susunan acara kegiatan pelaksanaan PkM di Sekolah Lentera Harapan (SLH) Curug Tangerang.

Tabel 1. Susunan Acara

\begin{tabular}{|c|c|}
\hline Waktu & Kegiatan \\
\hline 10.00 & Tim tiba di SLH Curug \\
\hline $10.00-10.45$ & Persiapan kegiatan workshop \\
\hline $10.45-11.00$ & Registrasi \\
\hline $11.00-11.05$ & Doa pembukaan \\
\hline $11.05-11.10$ & $\begin{array}{l}\text { Sambutan dari Fakultas Pariwisata: } \\
\text { Bapak Reagan Brian, S.ST., M.M. }\end{array}$ \\
\hline $11.10-11.35$ & $\begin{array}{l}\text { Workshop kreasi sorbet: } \\
\text { - } \quad \text { Pembagian kelompok dan bahan } \\
\text { bahan } \\
\text { - } \quad \text { Penjelasan tentang manfaat buah dan } \\
\text { sayur serta sorbet } \\
\text { - } \quad \text { Pembuatan sorbet }\end{array}$ \\
\hline $11.35-11.40$ & $\begin{array}{l}\text { Penyerahan souvenir kepada: } \\
\text { - } \quad \text { Bapak Josep Nasrani Marbun, M.Pd. } \\
\text { (Kepala Sekolah SMP SLH Curug) } \\
\text { - } \quad \text { Ibu Rosita Lolok Tage, S.Pd. (guru } \\
\text { pembimbing kegiatan tata boga SMP } \\
\text { SLH Curug) } \\
\end{array}$ \\
\hline $11.40-11.45$ & Doa penutup \\
\hline 11.45 & Foto bersama \\
\hline
\end{tabular}

\section{Hasil Kegiatan PkM}

Untuk mengevaluasi kegiatan yang dilakukan, pada akhir kegiatan siswa diberikan kuesioner evaluasi. Siswa diminta memilih satu dari lima pilihan jawaban yang dituliskan dalam angka 1-5, masing-masing menunjukkan sangat tidak setuju (1), tidak setuju (2), netral atau tidak berpendapat (3), setuju (4), sangat setuju (5). Tim menghitung hasil dari kuesioner dapat dijadikan bahan evaluasi. Berikut adalah hasil kuesioner:

Tabel 2. Hasil Kuesioner

\begin{tabular}{|c|c|}
\hline Pernyataan & Rata-rata \\
\hline \multicolumn{2}{|l|}{ Materi } \\
\hline Materi menarik & 4,3 \\
\hline $\begin{array}{l}\text { Materi mampu meningkatkan } \\
\text { pengetahuan tentang sorbet }\end{array}$ & 4,5 \\
\hline $\begin{array}{l}\text { Materi mampu menumbuhkan kreasi } \\
\text { tentang sorbet }\end{array}$ & 4,3 \\
\hline $\begin{array}{l}\text { Materi yang disampaikan memberikan } \\
\text { manfaat }\end{array}$ & 4,4 \\
\hline \multicolumn{2}{|l|}{ Fasilitator } \\
\hline Penjelasan fasilitator mudah dipahami & 4,5 \\
\hline Fasilitator bersikap komunikatif & 4,4 \\
\hline $\begin{array}{l}\text { Fasilitator memberikan kesempatan } \\
\text { untuk mencoba }\end{array}$ & 4,3 \\
\hline $\begin{array}{l}\text { Fasilitator memiliki pengetahuan yang } \\
\text { luas tentang produk }\end{array}$ & 4,4 \\
\hline
\end{tabular}

Berdasarkan hasil di atas menunjukkan bahwa siswa sudah memahami materi yang sudah diberikan, dan mampu meningkatkan pengetahuan tentang sorbet serta menumbuhkan kreasi tentang sorbet. Sedangkan fasilitator dinilai mampu untuk menyampaikan materi dan memiliki pengetahuan yang luas tentang produk.

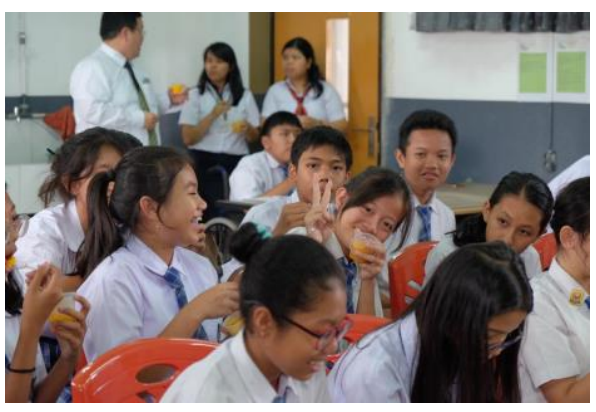

Gambar 5. Siswa Mencoba Hasil Kreasi Sorbet 
Kegiatan yang dilaksanakan telah memberikan hasil yaitu para siswa memahami kebutuhan vitamin bagi tubuh yang didapatkan dari buah dan sayur. Kegiatan ini juga merangsang kreativitas siswa dalam membuat kreasi sorbet sebagai alternatif untuk mendapatkan vitamin dari buah dan sayur. Para siswa sangat antusias selama mengikuti kegiatan dan memiliki keingintahuan yang tinggi. Hal ini dapat dilihat dari keikutsertaan aktif dari seluruh siswa yang menjadi peserta dan keberhasilan dalam pembuatan sorbet berbahan buah dan sayur.

\section{SIMPULAN}

Kegiatan ini dapat meningkatkan pengetahuan siswa tentang manfaat dari buah dan sayur, sehingga mampu memunculkan kepekaan para siswa untuk hidup sehat. Kegiatan ini dapat memberikan pengetahuan tentang kreasi makanan sehat yaitu melalui hidangan penutup sorbet berbahan buah dan sayur. Hal ini nantinya dapat meningkatkan minat konsumsi buah dan sayur pada para siswa. Untuk keberlanjutan kegiatan pengabdian kepada masyarakat, dapat dilakukan workshop lainnya yang mengajarkan olahan sehat yang dapat dikonsumsi oleh siswa.

\section{UCAPAN TERIMA KASIH}

Ucapan terima kasih disampaikan kepada LPPM Universitas Pelita Harapan, dan Dekan Fakultas Pariwisata Universitas Pelita Harapan yang telah mendukung dalam pelaksanaan kegiatan. Terima kasih juga disampaikan kepada Kepala Sekolah SMP Sekolah Lentera Harapan (SLH) Curug yang telah memberikan kesempatan untuk melaksanakan kegiatan, dan siswa SMP Sekolah Lentera Harapan (SLH) Curug yang sudah berpartisipasi dalam workshop.

\section{REFERENSI}

Anindyaputri, I. (2019). Dua Resep Sorbet, Camilan Segar Sehat yang Mudah Dibuat. Diaskes dari https://hellosehat.com/hidupsehat/nutrisi/nutrisi-dan-resep-sorbet/
Basleman, A., dan Mappa, S. (2011). Teori belajar orang dewasa. Jakarta: Rosda.

Dovey, T. M., Staples, P. A., Gibson, E. L., dan Halford, J. C. G. (2008). Food neophobia and 'picky/fussy' eating in children: A review. Appetite, 50(2-3), 181-193.

Nur, Khaeriyah (2012). Kualitas Es Krim dengan Penambahan Umbi Kentang (Solanum tuberosum L.) sebagai Bahan Pentabil. [Skripsi]. Makassar: Universitas Hasanuddin.

Proverawati, A., Prawirohartono, E. dan Kunjjoro, T. (2008). Jenis kelamin, pendidikan ibu, dan motivasi dari guru serta hubunganya dengan preferensi makan sekolah pada anak prasekolah di TK Universitas Muhammadiyah Purwokerto. Jurnal Gizi Klinik Indonesia, 5(2), 78-83.

Sartika, A. N. (2010). Preferensi Makanan Manis dan Berlemak Terhadap Kejadian Gizi Lebih Pada Remaja SMP di Kota Yogyakarta. Skrispi, Universitas Gadjah Mada. Diaskes dari http://etd.repository.ugm.ac.id/index.php?mo $\mathrm{d}=$ penelitian_detail\&sub=PenelitianDetail\&a ct=view\&typ=html\&buku_id=81950\&obyek _id $=4$

Scheule, B. dan Bennion M. (2015). Introductory Foods, $14^{\text {th }}$ Ed. New Jersey: Pearson 